Western University Scholarship@Western

Centre for the Study of International Economic Centre for the Study of International Economic

Relations Working Papers

Relations

1983

\title{
Labour Migration in a Model of North-South Trade
}

Ian Wooton

Follow this and additional works at: https://ir.lib.uwo.ca/economicscsier_wp

Part of the Economics Commons

Citation of this paper:

Wooton, Ian. "Labour Migration in a Model of North-South Trade." Centre for the Study of International Economic Relations Working Papers, 8308C. London, ON: Department of Economics., University of Western Ontario (1983). 
ISSN $\quad 0228--4235$

ISBN $0-7714-0426-3$

CENTRE FOR THE STUDY OF INTERNATIONAL ECONOMIC RELATIONS

WORKING PAPER NO.8308C

LABOUR MIGRATION IN A MODEL OF NORTH-SOUTH TRADE

Ian Wooton

This paper contains preliminary findings from research work still in progress and should not be quoted without prior approval of the author.

DEPARTMENT OF ECONOMICS UNIVERSITY OF WESTERN ONTARIO LONDON, CANADA

N6A $5 \mathrm{C} 2$
Departanent of Economics Library

MAY 121983

University of Western Ontario 
LABOUR MIGRATION IN A MODEL OF

NORTH-SOUTH TRADE

Ian Wooton *

\section{Abstract}

A dynamic general equilibrium model of the world economy is adopted to examine the benefits and drawbacks of labour migration to each of the participating regions. It is demonstrated that, especially in the long term, the migration of workers may be mutually beneficial: the region of immigration making production gains, while that of emigration perceives a higher demand for its products. In contrast to previous results, it is shown that no immigration limits would be imposed even if migrants' incomes were taxed and, indeed, differentiated payments to immigrants is sub-optimal.

December 1982

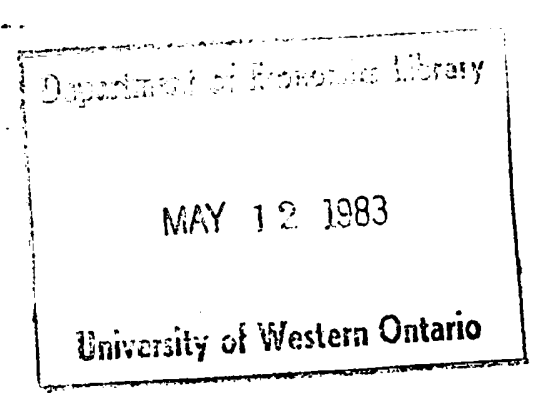


There has recently been considerable discussion of the impact of factor migration on trading economies. [See, in particular, Ramaswami (1968) and the symposium issue of the Journal of International Economics (1983).] In the framework of the Heckscher-Ohlin model it is well known that free trade will result in factor-price equalization. There is then absolutely no incentive for factors of either country to migrate to the other. In such a model the two countries are identical in every respect except that they may have different endowments of labour and capital. This assumption may be appropriate for the discussion of trade between similarly advanced economies but appears less satisfactory if the focus of analysis is trade between less-developed primary producers, commonly termed the "South", and the industrialized world, the "North".

A distinguishing characteristic between the two regions is taken to be the elasticity of labour supply: labour in the North being in considerably less elastic supply than the southern labour supply. A polar assumption is made that, instead of both regions having completely inelastic supplies of labour, one region has a perfectly elastic and the other a perfectly inelastic labour supply. Thus the North employs its entire labour force while the South, due to its overwhelmingly large population, can employ only part of its labour force in the trading sector.

The South may also be characterized as being dependent on the producers in the North for the capital used in the production process. Southern exports would then be composed of consumption goods while those of the North would include both capital and consumption goods. 
Several European nations, notably West Germany and Switzerland, have taken advantage of the availability of southern labour and have permitted workers to immigrate temporarily. The purpose of this paper is to use a model which embraces these characteristics of North-South trade to determine the benefits, or otherwise, to each region of this controlled labour migration. 1

The rest of the paper is as follows. Section 2 develops a dynamic model of labour migration and trade between the North and the South. Appropriate measures of each region's welfare are proposed. Section 3 considers the consequences of liberalization of migration quotas and shows that both regions may benefit. The optimal migration quotas are discussed. The impact of taxation of migrants' incomes is dealt with in Section 4. A summary of the results and their relation to the literature is presented in the concluding section.

\section{A Model of Migration and North-South Trade}

The structure of the model is derived from that of Findlay (1980a).

The services of the entire stocks of capital (K) and labour ( $L$ ) of the North (N) are employed in the production of a manufactured good (M) which may be used for either consumption or investment :

$$
q=q\left(k_{M}\right)
$$

where $k_{M}$ is the capital-labour ratio in manufacturing and $q$ is the output of manufactures per worker. The production function is assumed to conform to the Inada conditions.

The wage rate in the North is equal to the marginal product of labour in manufacturing,

$$
w_{N}=q\left(k_{M}\right)-q^{\prime}\left(k_{M}\right) k_{M},
$$


while the rental on capital is equal to its marginal product,

$$
r_{N}=q^{\prime}\left(k_{M}\right)
$$

The labour force grows at an exogenously given rate (n):

$$
\mathrm{I}_{\mathrm{N}}=\widetilde{\mathrm{I}}_{\mathrm{N}} \exp (\mathrm{nt}) \text {. }
$$

In the steady-state, the rate of growth of the northern economy must be $n$.

The North permits some southern natives $\left(\mathrm{L}_{G}\right)$ to be temporary workers in manufacturing. These "gastarbeiters" do not displace any northerners but, instead, are additions to the northern force and are paid the same real wage, which is assumed to be greatern than the souther wage. ${ }^{2}$ The level of employment is determined by quota as a proportion of the native northern labour force,

$$
L_{G}=\tau L_{N},
$$

where $0<\tau<\infty$. Consequently gastarbeiter employment grows at the same exogenous rate as the growth of the native population.

The capital-labour ratio in manufacturing $\left(k_{M}\right)$ is clearly less than the quantity of capital owned by each northern citizen ( $\left.k_{N}\right)$ because employment in the North exceeds the native population:

$$
k_{M}=\frac{K_{N}}{L_{N}+L_{G}}=\frac{K_{N}}{(1+\tau) L_{N}}=\frac{k_{N}}{1+\tau}
$$

Per capita income of northerners is the sum of the rentals on the services of those factors owned by them:

$$
\mathrm{y}_{\mathrm{N}}=\mathrm{w}_{\mathrm{N}}+\mathrm{r}_{\mathrm{N}} \mathrm{k}_{\mathrm{N}}
$$

A constant proportion (S) of northern income is saved through purchases of manufactures as additions to the capital stock. Gastarbeiters, owning none of the capital stock, are paid the marginal product of their labour, the real wage,

$$
y_{G}=w_{N}
$$


of this, the immigrant remits a fixed proportion $(r)$ to his native region where it is consumed, the total transfer amounting to

$$
R=r y_{G} L_{G} \cdot
$$

Both native northerner and gastarbeiter divide their consumption expenditures between manufactures and primary product. The total northern demand for imports of primary product is a function of the consumption expenditures made by natives and immigrants and of the terms of trade $(\theta)$, manufactures per unit of primary product:

$$
I_{N}=m\left[\theta,(1-s) y_{N}\right] L_{N}+\tilde{m}\left[\theta,(1-r) y_{G}\right] L_{G},
$$

where $\mathrm{m}[\mathrm{]}$ and $\tilde{m}[]$ are the per capital import demands of natives and gastarbeiters, respectively. It is assumed that the partial derivatives conform to

$$
\mathrm{m}_{1}, \tilde{m}_{1}<0<\mathrm{m}_{2}, \tilde{m}_{2}
$$

and that the income elasticities of import demand are unity.

The modern sector of the South (S) produces, according to the usual assumptions, a purely consumption-oriented primary good (P):

$$
\Pi=\Pi\left(k_{\mathbf{p}}\right) \text {, }
$$

where $k_{P}$ is the capital-labour ratio in primary production and $\Pi$ is output per worker. This product may be consumed domestically or traded with the North in return for manufactured goods for consumption or investment. In the hinterland of the South there is a much larger traditional sector producing non-traded goods, which provides work for all labour not employed in primary production. In such a structure labour is in nearly perfectly elastic supply in the modern sector at the given real wage of the hinter land. ${ }^{3}$ Labour is employed in primary production to the point at which the wage equals its marginal product: 


$$
\tilde{w}_{S}=\Pi\left(k_{P}\right)-\Pi^{\prime}\left(k_{P}\right) k_{P}
$$

This determines an unique capital-labour ratio $\left(\tilde{k}_{p}\right)$ for primary production. The rental rate in the modern sector is

$$
\tilde{r}_{S}=\Pi^{\prime}\left(\tilde{k}_{p}\right) \text {. }
$$

The per capita income of the South's modern sector is the sum of domestic output and remittances from abroad:

$$
\Psi=\Pi\left(\tilde{k}_{P}\right)+R / \theta_{S}
$$

where $\mathrm{L}_{\mathrm{S}}$, domestic employment in the modern sector, is determined by the existing capital stock and $\tilde{k}_{\mathrm{P}}$. The capital stock is augmented by saving out of profits at a constant rate $(\sigma)$. This is traded for manufactures which are used as investment goods. Given that the terms of trade are $\theta$, the rate of profit in primary production is

$$
\gamma=\theta \tilde{r}_{s} \text {. }
$$

The common rate of growth of capital, domestic income, and domestic employment is therefore

$$
g=\sigma \gamma
$$

Southern import demand consists of demands for manufactured goods for both investment and consumption. Consumption demand for manufactures is a function of the consumption expenditure of southerners and of the terms of trade $\left(\frac{1}{\theta}\right)$. The per capita expenditure on consumption is per capita income less per capita saving:

$$
e_{s}=\Psi-\tilde{\sigma r} \tilde{k}_{P}
$$

Thus the demand for imports of manufactures is

$$
I_{S}=i_{s} L_{S}=\left\{\sigma \theta \tilde{r}_{s} \tilde{k}_{P}+\mu\left[\frac{1}{\theta}, e_{S}\right]\right\}_{S}
$$

where $\mu[]$ is the per capita consumption demand. It is assumed that 
$\mu_{1}<0<\mu_{2}$ and that the income elasticity of consumption demand is unity. In the absence of international capital movements, trade and transfers must be balanced such that

$$
\theta I_{N}=I_{S}-R \text {. }
$$

At any instant, with a given labour-migration quota, the capital stocks of the two regions and the northern labour force are fully determined. The capital-labour ratio in primary production is known, and so also is the level of southern employment. Therefore the terms of trade shall adjust to any disturbances to maintain trade balance in the short run. Substituting for $I_{N}, I_{S}$ and $R$ and letting $\lambda=I_{S} / L_{N}$, the ratio of native workforces in the two regions, an implicit expression for the terms of trade at any instant may be derived:

$$
\theta=\frac{\lambda \mu\left[\frac{1}{\theta}, e_{S}\right]-r \tau y_{G}}{m\left[\theta,(1-s) y_{N}\right]+\tau \tilde{m}\left[\theta,(1-r) y_{G}\right]-\sigma \lambda \tilde{r}_{S} \tilde{k}_{P}}
$$

In the long run, a necessary condition for a steady-state equilibrium is that the growth rates of the North and South are equal. Thus :

$$
\mathfrak{n}=\sigma \theta \tilde{\mathbf{r}}_{\mathbf{s}} \text {. }
$$

The steady-state terms of trade are clearly

$$
\theta *=\frac{\mathrm{n}}{\tilde{\sigma r}_{\mathrm{S}}}
$$

The long-run value of $k_{N}\left(k_{N}^{*}\right)$ that corresponds to a growth rate of $n$ and quota $\tau$ is implicitly derived from:

$$
\begin{aligned}
\dot{k}_{\mathrm{N}} & =s y_{N}-n k_{N}=0 \\
\Rightarrow s y_{N}^{*} & =n k_{N}^{*}
\end{aligned}
$$


Corresponding to $\mathrm{k}_{N}^{*}$ and $\tau$ are the steady-state values of $\mathrm{k}_{M}, \mathrm{y}_{\mathrm{N}}$, and $\mathrm{y}_{G}$. In the steady state, the only variable not fully determined is the relative size of one trading sector to the other. As the size of northern labour force is exogenously determined southern employment, and hence the scale of production in the South's trading sector, must adjust to maintain balanced trade in the long run. The steady-state value of $\lambda$ is therefore implicitly determined by the steady-state form of equation (20), which may be rearranged as :

$$
\lambda *=\frac{\theta *\left\{\mathrm{~m}\left[\theta *,(1-\mathrm{s}) \mathrm{y}_{\mathrm{N}}^{*}\right]+\tau \tilde{\mathrm{m}}\left[\theta *,(1-\mathrm{r}) \mathrm{y}_{\mathrm{G}}^{*}\right]\right\}+\mathrm{rTy}_{\mathrm{G}}^{*}}{\mu\left[\frac{1}{\theta *}, e_{\mathrm{S}}^{*}\right]+\mathrm{nk}_{\mathrm{P}}}
$$

In the succeeding sections of this paper, the consequences of increasing the quota on southern labour migration are discussed. Appropriate indicators of the welfare of each region are needed. As the immigration policies cannot affect the employment of northern natives, their per capita income is used as a measure of the North's welfare. The level of employment is endogenous in the modern sector of the South and the incomes of its workers are composed of their (fixed) wages and their share of the gastarbeiters' remittances. As a result, the welfare measure adopted must take into account both the level of employment in the South relative to that of northern natives and the per capita incomes of those employed. Meeting these criteria is southern national income per northerner:

$$
\mathrm{y}_{\mathrm{S}}=\lambda \Psi
$$

In order to investigate the benefits of a gastarbeiter program the effects of increasing the migration quota are examined to determine the initial impact and the new steady-state. 


\section{An Increase in the Labour Migration Quota}

The per capita income of the gastarbeiters falls initially because

an increase in the intensity of labour in production, with a fixed capital stock, depresses the real wage

$$
\left.\frac{d y_{G}}{d \tau}\right|_{k_{N}}=\frac{1}{1+\tau} k_{M}^{2} q^{\prime \prime}\left(k_{M}\right)<0 .
$$

Although northern wage income is similarly depressed, the rise in the productivity of capital more than compensates,

$$
\left.\frac{d y_{N}}{d \tau}\right|_{k_{N}}=\frac{-\tau}{1+\tau} k_{M}^{2} q^{\prime \prime}\left(k_{M}\right)>0 .
$$

This is shown in Figure 1. With immigration quota $\tau_{1}$ the northerners receive a product equal to $A+B+C+D$ while the gastarbeiters receive $E+F$, representing a per capita wage of $y_{S 1}$. A higher quota of $\tau_{2}$ yields $A+B+C+D+E+G$ for the natives and $F+H$ for the immigrants. If $H>E$ the total product of southern labour in the North increases. Northern income in terms of domestic product has risen. The behaviour of the terms of trade has to be examined before the welfare implications can be determined.

In the short run capital stocks cannot adjust to the new steady-state levels which are implied by greater migration. As international payments must constantly be in balance, the terms of trade will adjust in response to any change in labour migration,

$$
\frac{d \theta}{d \tau}=\frac{\theta_{m_{2}}(1-s) \frac{d y_{N}}{d \tau}+\left\{\theta \tilde{m}_{2}(1-r)+r\left(1-\frac{\mu_{2}}{\theta}\right)\right\}\left\{\tau \frac{d y_{G}}{d T}+y_{G}\right\}}{\lambda \frac{d i}{d \theta}-\left\{m\left[\theta,(1-s) y_{N}\right](1-\eta)+\tau \tilde{m}\left[\theta,(1-r) y_{G}\right](1-\tilde{\eta})\right\}}
$$

where $\eta$ and $\tilde{\eta}$ are the price elasticities of northern natives and gastarbeiters, respectively. The numerator is positive if total gastarbeiter income rises with 
the increased migration and may still be greater than zero if their income falls, due to the increased northern income. The first term of the denominator is positive if the change in southern import demand due to the price effect of a change in the terms of trade is greater than the change in demand induced by the reduction in value of gastarbeiter remittances. If those living in the North have sufficiently elastic demands for imports of primary products then the entire denominator is positive. Thus an increase in the migration quota which results in higher total gastarbeiter income will induce an improvement in the terms of trade in the South, if the demand for primary products is relatively elastic. This is an intuitive result--a larger labour force produces more manufactures which are traded for the same output of primary products and so the relative price of manufactures falls.

Short of adopting a policy which changes the natural growth rate of its labour force, the North is unable to affect the steady-state terms of trade. The lasting impact of labour immigration will be on capital accumslation. In the long run, northern savings must be just sufficient to equip each new member of the labour force with the steady-state quantity of capital. In order to determine how the capital holdings of northerners are affected by changes in the quota, equation $(22)$ is differentiated with respect to $\tau$ :

$$
\frac{\mathrm{dk}_{\mathrm{N}}^{*}}{\mathrm{d \tau}}=\frac{\frac{-\tau}{(1+\tau)} \mathrm{sk}_{M}^{* 2} \mathrm{q}^{\prime \prime}\left(\mathrm{k}_{M}^{*}\right)}{\mathrm{n}-s\left\{\mathrm{q}^{\prime}\left(\mathrm{k}_{M}^{*}\right)+\frac{\tau}{(1+\tau)} k_{M}^{*} \mathrm{q}^{\prime \prime}\left(k_{M}^{*}\right)\right\}}
$$

The numerator is positive. If the capital accumulation process is stable then, in the region of the steady-state capital-1abour ration, $\mathrm{k}_{\mathrm{N}}^{*}$, the denominator must also be positive. The quantity of capital owned by each native of the North rises when the immigration quota is raised. Now, 


$$
\frac{\mathrm{dy}_{\mathrm{N}}^{*}}{\mathrm{~d} T}=\frac{\mathrm{n}}{\mathrm{S}} \frac{\mathrm{dk}_{\mathrm{N}}^{*}}{\mathrm{dT}}
$$

and so the long-run per capita income of northerners is an increasing function of the labour immigration quota. The North undoubtedly gains from increased immigration: clearly free mobility of labour would yield the greatest benefit. 4

The change in the capital-labour ratio in manufacturing as a result of a change in the quota is

$$
\frac{\mathrm{dk}_{M}^{*}}{\mathrm{~d} \tau}=\frac{\frac{1}{(1+\tau)}\left\{s q^{\prime}\left(k_{M}^{*}\right)-n\right\}_{M}^{*}}{n-s\left\{q^{\prime}\left(k_{M}^{*}\right)+\frac{\tau}{(1+\tau)} k_{M}^{*} q^{\prime \prime}\left(k_{M}^{*}\right)\right\}} .
$$

The numerator is negative, being the difference between savings out of profits and total investment. The capital-labour ratio in northern production declines with increased immigration. Hence, though the per capita native holdings of capital rise, this increase is proportionately less than the inflow of additional labour. As a result, the wage rate falls,

$$
\frac{d y_{G}^{*}}{d \tau}=-k_{M}^{*} q^{\prime \prime}\left(k_{M}^{*}\right) \frac{d k_{M}^{*}}{d \tau}<0 .
$$

The increase in northern capital holdings means that the eventual decline in the wage rate is less than the instantaneous fall. This is illustrated in Figure 2. An increase in the immigration quota from $\tau_{1}$ to $\tau_{2}$ would initially lead to a drop in the wage rate from $y_{G 1}^{*}$ to $y_{G 2}$. Once capital stocks adjust to their new steady-state level the wage rate rises to $y_{G 2}^{*}$. If the North were to permit free immigration, labour would flow from the South until the northern wage was drawn down to the prevailing southern wage.

$$
y_{G}^{*}=\theta * \tilde{w}_{S}
$$


The southerners who remain in their homeland will be affected by the immigration policies of the North in two respects. Firstly, there will be changes in the quantity of manufactures remitted by gastarbeiters and, secondly, the North's demand for primary products will change. Differentiating the steady-state employment ratio,

$$
\frac{d \lambda *}{d \tau}=\frac{\theta x_{2}(1-s) \frac{d y_{N}^{*}}{d T}+\left\{\theta \tilde{m}_{2}(1-r)+r\left(1-\frac{\mu_{2}}{\theta *}\right)\right\}\left\{y_{G}^{*}+\tau \frac{d y_{G}^{*}}{d \tau}\right\}}{\mu\left[\frac{1}{\theta *}, e_{S}^{*}\right]\left\{1-\frac{\mu_{2} x T}{\mu[] \theta * \lambda *} y_{G}^{*}\right\}+n \tilde{k}_{P}}
$$

If total gastarbeiter income rises then southern employment increases relative to the population of the North; if it should fall, the increased demand by northerners for primary products might still result in higher employment in primary production. Clearly the initiation of migration is beneficial to the South. If total gastarbeiter income should fall as the quota is increased southern employment may continue to risebut the volume of remittances will fall. The welfare criterion of the South is to maximize national income per northerner:

$$
\frac{d y_{S}^{*}}{d \tau}=\left\{\Pi\left(\tilde{k}_{P}\right) \frac{d \lambda *}{d \tau}+\frac{r}{\theta *}\left(\frac{d y_{G}^{*}}{d \tau}+y_{G}^{*}\right)\right\}
$$

The South might wish to impose an emigration quota at a level less than employment maximization.

It has been shown that the North will favour free labour mobility, domestic income rises while the steady-state terms of trade do not change. The South certainly gains from labour emigration but may want to restrict it to some level less than free mobility. 
4. Optimal Migration and Income Taxation

4.1 Northern Taxation of Gastarbeiter Earnings

Suppose that the North were to tax proportionately the income of labour in the North and redistribute the proceeds to its natives. As a result of the taxation and transfer, ceteris paribus, the per capita income of northerners will rise while that of gastarbeiters will fall. In Ramaswami's (1968) discussion of factor mobility, it was noted that the optimal migration policy in the face of taxation would not be free labour immigration, because the tax revenues ultimately fall as the inflow of workers continues. His was, however, only a short-run analysis which took no account of the changes in capital accumulation which occur as a result of the policies.

Gastarbeiter net income is now the wage less tax,

$$
\hat{y}_{G}=(1-t) w_{N}
$$

where $t$ is a proportional income tax. Net northern income is the sum of rewards for capital and labour services together with the redistributed revenues from the tax on gastarbeiter earnings:

$$
\hat{y}_{N}=\left(1+t_{T}\right) w_{N}+r_{N} k_{N}
$$

The immigration quota chosen by the North should maximize long-run northern income. In the steady state

$$
\mathbf{s} \hat{y}_{N}^{*}=\mathbf{n} k_{N}^{*} \text {. }
$$

Differentiating $\mathrm{k}_{\mathrm{N}}^{*}$ with respect to the quota:

$$
\frac{d k_{N}^{*}}{d \tau}=\frac{s\left\{t \dot{w}_{N}^{*}-\frac{T}{1+\tau}(1-t) k_{M}^{* 2} q^{\prime \prime}\left(k_{M}^{*}\right)\right\}}{n-s\left\{q^{\prime}\left(k_{M}^{*}\right)+\frac{\tau}{1+T}(1-t) k_{M}^{*} q^{\prime \prime}\left(k_{M}^{*}\right)\right\}}>0
$$

Hence : 


$$
\frac{d \hat{y}_{N}^{*}}{d T}=\frac{n}{S} \frac{d k_{N}^{*}}{d \tau}>0
$$

Northern income is an increasing function of the level of immigration. Even when immigrant workers are taxed, the optimal policy is free mobility of labour.

Under such a policy, workers will continue to migrate as long as there is a difference between the net wage rates in the two regions. Therefore, in equilibrium,

$$
\hat{y}_{G}^{*}=\theta^{*} \tilde{w}_{S}
$$

Differentiating with respect to the tax rate:

$$
\frac{d k_{M}^{*}}{d t}=\frac{-w_{N}^{*}}{(1-t) k_{M}^{*} q^{\prime \prime}\left(k_{M}^{*}\right)}>0 .
$$

The higher the tax rate, the greater the intensity of capital in production to enable labour to be paid the same net wage as before. Using equations (37) and (41), it can be shown that both the per capita incomes and capital holdings of northerners in the steady state are diminished when taxes are imposed on freely mobile labour:

$$
\begin{aligned}
& \frac{d k_{N}^{*}}{d t}=-\frac{t}{(1-t)}(1+\tau)^{2} \frac{d_{M}^{*}}{d t}<0 \\
& \frac{d_{y}^{*}}{d t}=\frac{n}{s} \frac{d k_{N}^{*}}{d t}<0
\end{aligned}
$$

It is clear that it would be damaging for the North to impose any positive rate of taxation.

This is illustrated in Figure 3. The net wage of gastarbeiters must always be $\theta^{*} \tilde{w}_{S}$. If the tax rate were raised from zero to $t_{1}$, the northern steady-state capital holdings would fall from $k_{\mathrm{N} 1}^{*}$ to $k_{\mathrm{N} 2}^{*}$. Tax revenues 
would be accounted for by the checkered area which had been, before the tax was imposed, part of the northern income anyway. The income lost to the North is represented by the striped area.

\subsection{Southern Taxation of Gastarbeiter Earnings}

If the south were to tax its non-resident citizens' earnings and redistribute these to residents for consumption this would, in effect, be the same as inducing a change in the remittance parameter, $r .6$

With a particular quota on migration, the change in employment in the South as a result of a change in the tax rate, $r$, is

$$
\frac{d \lambda^{*}}{d r}=\frac{\tau y_{G}^{*}}{I_{N}}\left\{\frac{1-\left(\theta^{*} \tilde{m}_{2}+\frac{\mu_{2}}{\theta^{*}}\right)}{i_{S}-\mu_{2} \frac{r_{T}}{\theta^{*} \lambda^{*}} y_{G}^{*}}\right\}
$$

The denominator is positive. The sign of the numerator depends on the marginal propensities of consumption of the resident and non-resident southern workers. The tax merely redistributes consumption expenditures from one group of workers to another. If the latter group should have a greater propensity to consume primary products than the former, southern employment will increase as the tax is levied. If the consumption propensities of both resident and non-resident southerners are the same, the tax will have no impact on employment. The income of the South would, of course, rise because of the tax revenues:

$$
\frac{d y_{S}^{*}}{d r}=\frac{T}{\theta} y_{G}
$$

If the North were following its optimal policy of free immigration and the South were to impose a tax on its non-residents' earnings, then this tax will cause a reduction in northern steady-state employment, because 
a higher wage will have to be paid for the gastarbeiter to receive the same net-of-tax earnings. The impact on southern employment is

$$
\frac{d \lambda^{*}}{d r}=\frac{\theta^{*} m_{2}(1-s) \frac{d y_{N}^{*}}{d r}+\left\{\theta^{*} \tilde{m}[]+r y_{G}^{*}\right\} \frac{d \tau}{d r}+\left(1-\frac{\mu_{2}}{\theta^{*}}\right) \frac{\tau y_{G}^{*}}{(1-r)}}{i_{S}-\mu_{2} \frac{r T}{\theta^{*} \lambda^{*}} y_{G}^{*}}
$$

The denominator is positive. The first two terms in the numerator are negative, reflecting the effects of the fall in northerners' incomes and gastarbeiters' employment on the demand for primary products. The last term is positive--southern demand for primary goods rises due to the income from tax revenues. If southern workers have similar marginal propensities to consume then the income tax will almost certainly have a negative impact on southern employment in primary production because of the lower northern income. Thus, though tax revenues may have grown, the combined effects of revenue and employment on southern national income per northerner is uncertain.

\section{Summary and Conclusions}

This paper has studied the potential benefits and disadvantages of labour migration to each of two regions in a world economy. Two strong assumptions were adopted: firstly, that one region has a perfectly elastic and the other a perfectly inelastic supply of labour and, secondly, that the two regions are each specialized in their production activities. The conduct of the labour migration process was styled upon that exercised by post-war Western Europe--workers being permitted to work in the northern country for fixed periods and not being allowed to permanently settle.

The instantaneous impact of a change in the quantity of migration brings a higher per capita income to the citizens of the North, due to 
their appropriation of the production surplus. The wage rate is depressed but the northerners are compensated by a higher rate of profit. Demand for primary products may rise and, as capital stocks and hence southern production is fixed in the short run, this will show itself as a temporary improvement in the terms of trade of the south.

The North is unable to induce any change in the long-run terms of trade by its immigration policy. Prolonged immigration does however bring about an increase in steady-state capital holdings and thence a greater rise in northern income than appeared initially. Consequently wage rates partially recover from their fall and total gastarbeiter income rises. This rise in northern earnings induces an increase in southern employment in response to the greater demand for primary products. Therefore, at least for initial levels of migration, the gastarbeiter program benefits both the country of emigration and that of immigration.

The optimal immigration strategy of the North has been shown to be one of free, unrestricted mobility with no discriminatory taxation of gastarbeiters. Additionally, proposals that suggest the south should tax its emigrants have been shown to be misguided, in that such taxation may reduce foreign demand for the region's product and thereby reduce national income.

Clearly, another strategy the North might adopt would be to permit an outflow of capital to the south rather than an inflow of labour. Saavedra-Rivano and Wooton (1983) discuss the different production conditions under which the North would find one scheme more rewarding than the other. They show however that capital mobility does not have the benign consequences for the South that result from labour mobility. Given the choice, the South would certainly opt for a regime of labour mobility. 


\section{Footnotes}

* University of Western Ontario. The author wishes to thank Jagdish Bhagwati, Ronald Findlay, James Melvin and Neantro Saavedra-Rivano for their comments and suggestions on this paper.

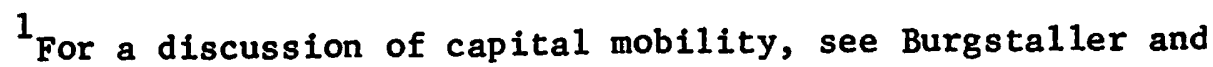
Saavedra-Rivano (1981). Saavedra-Rivano and Wooton (1983) provide a comparison of these two regimes of factor mobility.

2 The immigrants are never permitted to settle permanently, being returned to the South and replaced by new workers at the end of their contracts. Consequently they acquire none of the northern capital stock nor are their earnings ever considered as part of northern income.

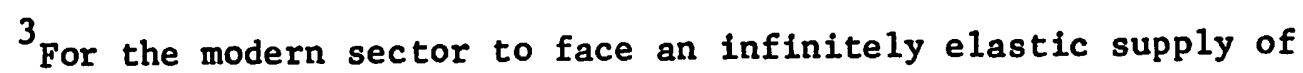
labour it is not necessary to assume that the marginal product of labour in the hinterland is zero. On this, see Findlay (1980b).

4 Under free mobility, labour movements will occur until the real wage in the North equals that in the South. This will occur either when the surplus labour in the South is fully employed, making both regions "northern"; or when both regions face a perfectly elastic supply of labour, each then being a "southern" economy.

5 This is equivalent to the North discriminating against immigrant workers in the payment of wages.

6 Residents' wages may also be taxed, with the revenues redistributed for consumption, without any change in the analysis. 


\section{REFERENCES}

Bhagwati, J. N. (1979) "International Factor Movements and National Advantage," The Ninth Ramaswami Lecture, Indian Economic Review, Vol. 14 (NS), October, pp. 73-100.

Bhagwati, J.N., and T.N. Srinivasan (1983) "On the Choice Between Capital and Labour Mobility, Journal of International Economics, Vol. 13, forthcoming.

Burgstaller, A., and N. Saavedra-Rivano (1983) "Capital Mobility and Growth in a North-South Model," Journal of Development Economics, forthcoming. Calvo, G., and S. Wellisz (1983) "International Factor Mobility and National Advantage," Journal of International Economics, Vol. 13, forthcoming. Findlay, R. (1980a) "The Terms of Trade and Equilibrium Growth in the World Economy," American Economic Review, Vo1. 70, June, pp. 291 -299. Findlay, R. (1980b) "On W. Arthur Lewis' Contributions to Economics," Scandinavian Journal of Economics, Vol. 82, pp. 62-79.

Lewis, W. A. (1954) "Economic Development with Unlimited Supplies of Labour," Manchester School of Economic and Social Studies, Vol. 22, May, pp. 139-191

MacDouga11, G. D. A. (1960) "The Benefits and Costs of Private Investment from Abroad: A Theoretical Approach," Economic Record, Vol. 37, March, pp. 13-35.

Ramaswami, V. K. (1968) "International Factor Movements and the National Advantage," Economica, Vo1. XXXV, August, pp. 309-310。 
Saavedra-Rivano, N., and Ian Wooton (1983) "The Choice Between International Labour and Capital Mobility in a Model of North-South Trade," Journal of International Economics, Vol. 13, forthcoming. Wong, K. (1983) "On Choosing Among Trade in Goods and International Capital and Labor Mobility: A Theoretical Analysis," Journal of International Economics, Vol. 13, forthcoming. 


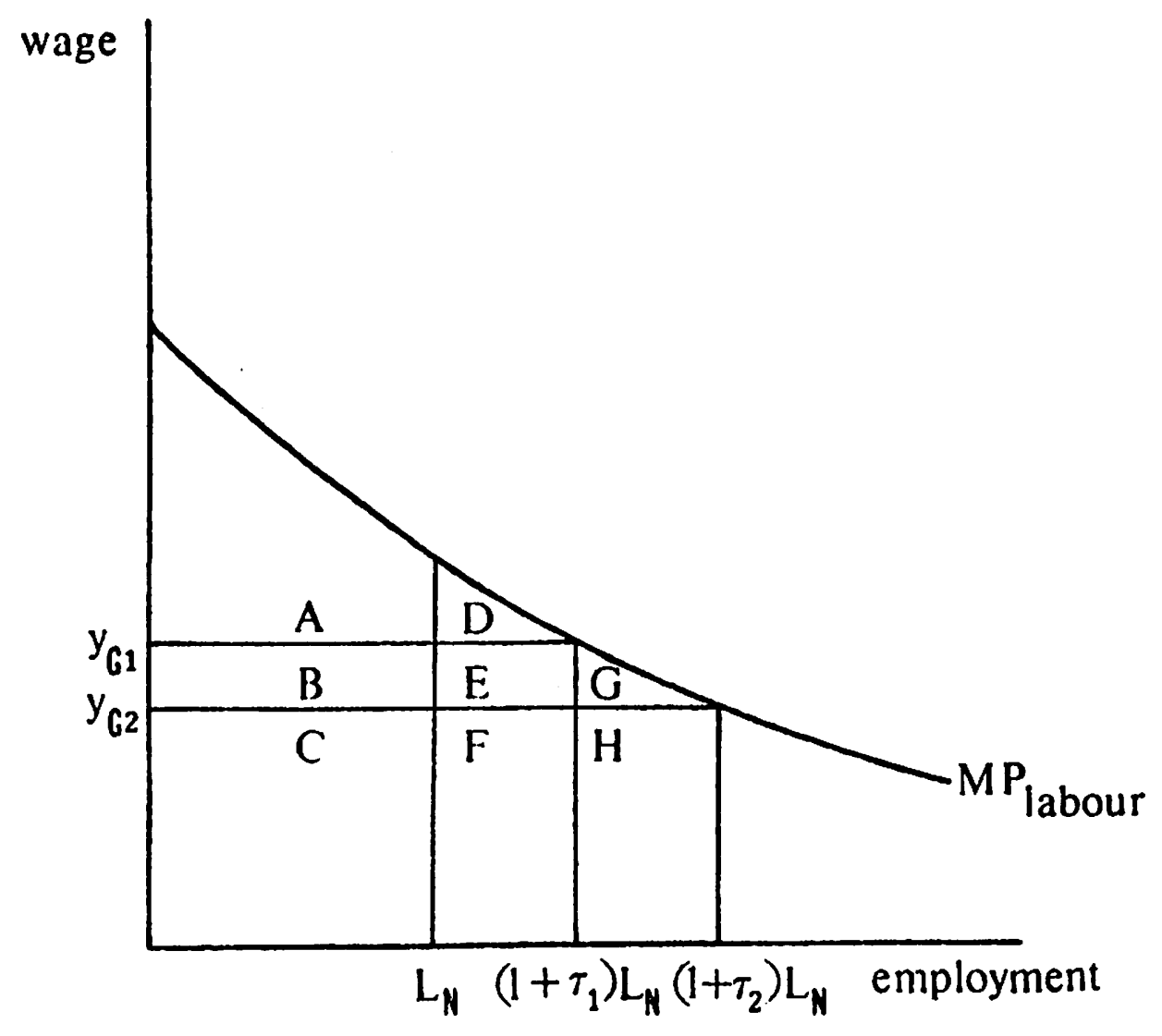

Figure 1 


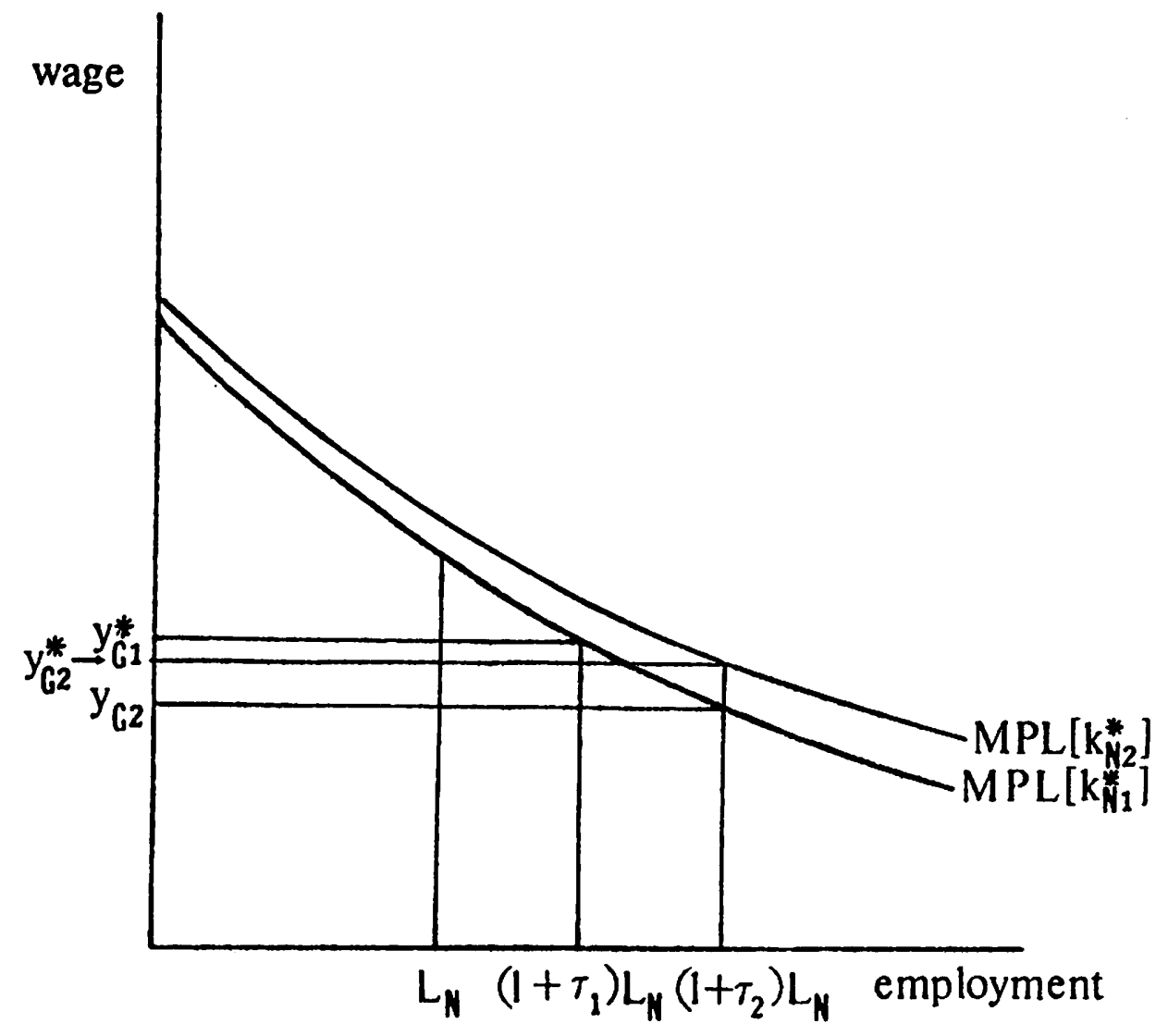

Figure 2 


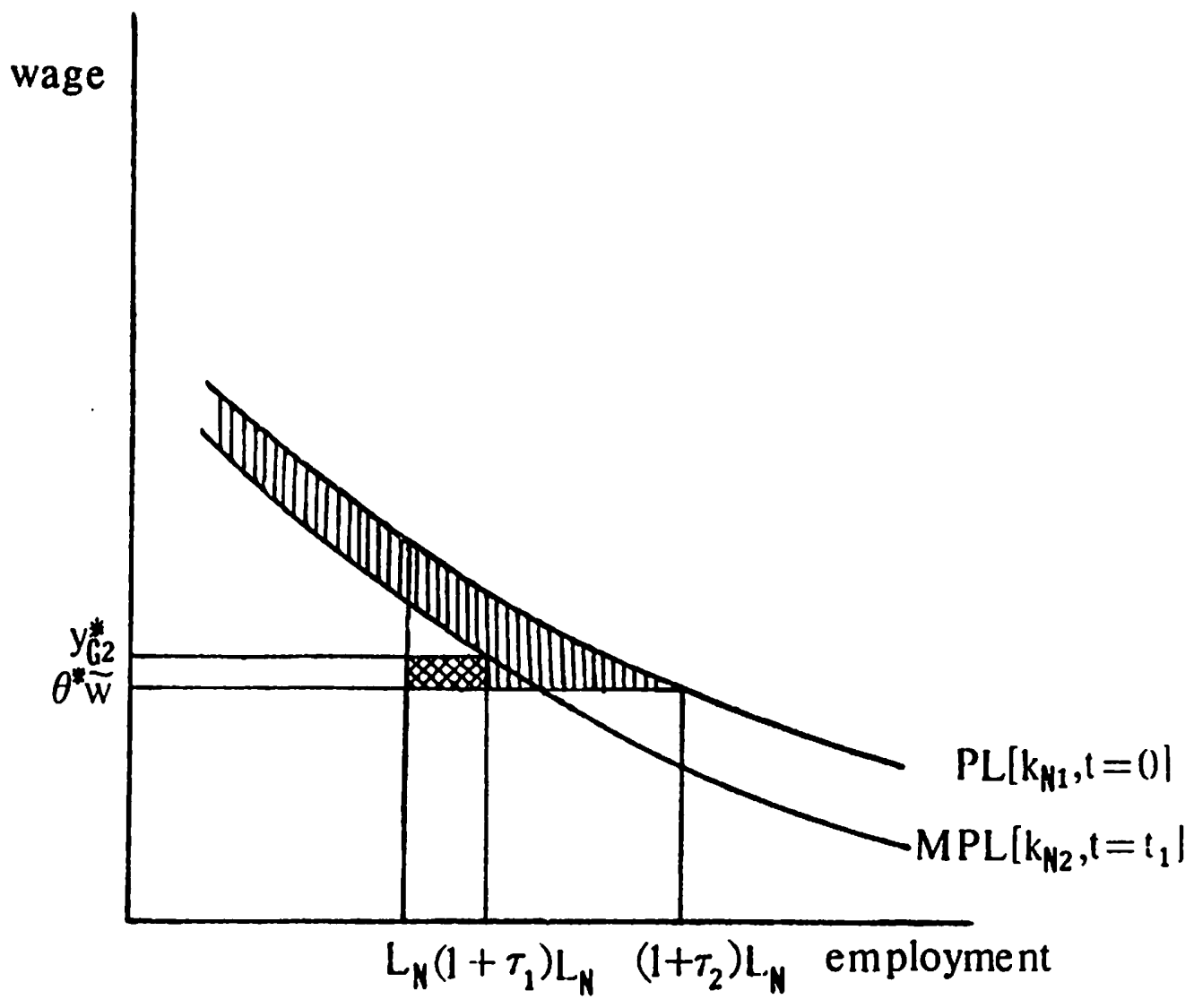

Figure 3 
8201C Manning, Richard and James R. Karkusen: DYNAMIC NON-SUBSTITUTION AND LONG RUN PRODUCTION POSSIBILITIES

8202C Feenstra, Robert and Ken Judd: TARIFFS, TECHNOLOGY TRANSFER, AND WELFARE

8203C Ronald $W$. Joneg and Douglas D. Purvis: INTERNATIONAL DIFFERENCES IN RESPONSE TO COMHON EXTERNAL SHOCKS: THE ROLE OF PURCHASING POWER PARITY

8204C James A. Brander and Barbara J. Spencer: INDUSTRIAL STRATEGY WITH COMMITTED FIRYS

8205C Whalley, John: THE NORTH-SOUTH DEBATE AND THE TERMS OF TRADE: AN APPLIED GENERAL EQUILIBRIUM APPROACH

8206C Betancourt, Roger; Christopher Clague and Arvind Panagariya: CAPITAL UTILIZATION IN GENERAL EQUILIBRIUM

8207C Mansur, Ahsan H.: ON THE ESTIMATION OF IMPORT AND EXPORT DEMAND ELASTICITIES AND ELASTICITY PESSIMISM

8208C Whalley, J. and Randy Wigle: PRICE AND QUANTITY RIGIDITIES IN ADJUSTMENT TO TRADE POLICY CHANGES: ALTERNATIVE FORMULATIONS AND INITIAL CALCULATIONS

8209C DSU Jimenez, E.: SQUATTING AND COMMUNITY ORGANIZATION IN DEVELOPING COUNTRIES: A CONCEPTUAL FRAMEWORK

8210C Grossman, G.H.: INTERNATIONAL COMPETITION AND THE UNIONIZED SECTOR

8211C Laidler, D.: FRIEDMAN AND SCHWARTZ ON MONETARY TRENDS--A REVIEW ARTICLE

8212C Imam, H: and John Whalley: INCIDENCE ANALYSIS OF A SECTOR SPECIFIC MINIMUN WAGE IN A THO SECTOR HARRIS-TODARO MODEL

8213C Markusen, James R. and James R. Melvin: THE GAINS FROM TRADE THEOREH WITH INCREASING RETURNS TO SCALE

8214C Harris, Richard: INDUSTRIAI ORGANIZATION AND THE GENERAL EQUILIBRIUM COSTS OF PROTECTION IN SMALI OPEN ECONOMIES

8215C Laidler, David: DID MACROECONOMICS NEED THE RATIONAL EXPECTATIONS REVOLUTION?

8216C John Whalley and Randall Wigle: ARE DEVELOPED COUNTRY MULTILATERAL TARIFF REDUCTIONS NECESSARILY BENEFICIAL FOR THE U.S.? 
8217 Bade, Robin and Michael Parkin. IS STERLING M3 THE RIGHT AGGREGATE?

8218 Kosch, Bernd. FIXED PRICE EQUILIBRIA IN OPEN ECONOMIES

$\underline{1983}$

8301 Harrison, Glenn and Larry Kimbell. ON THE SOLUTION OF GENERAL EQUILIBRIUM MODELS

8302 Melvin, James. A GENERAL EQUILIBRIUM ANALYSIS OF CANADIAN OIL POLICY

8303 Markusen, James and Lars Svensson. TRADE IN GOODS AND FACTORS WITH INTERNATIONAL DIFFERENCES IN TECHNOLOGY

8304 Mohammad, Sharif and John Whalley. RENT SEEKING IN INDIA: ITS COSTS DSU AND POLICY SIGNIFICANCE

8305 Jimenez, Emmanuel. TENURE SECURITY AND URBAN SQUATTING DSU

8306 Parkin, Michae1. WHAT CAN MACROECONOMIC THEORY TELL US ABOUT THE WAY DEFICITS SHOULD BE MEASURED

8307 Parkin, Michael. THE INFLATION DEBATE: AN ATTEMPT TO CLEAR THE AIR. 